\title{
UNDERSTANDING THE IMPACT OF INSTITUTIONAL FACTORS ON ASNAF SUSTAINABILITY: A PLS-SEM APPROACH
}

\author{
M Ashraf Al Haq ${ }^{1}$, Norazlina Abd Wahab² and Md. Mahmudul Alam³
}

\author{
${ }^{1}$ Islamic Business School, Universiti Utara Malaysia, glinklondon@gmail.com \\ 2 Islamic Business School, Universiti Utara Malaysia, norazlina.aw@uum.edu.my \\ ${ }^{3}$ School of Economics, Finance and Banking, Universiti Utara Malaysia, mahmudul@uum.edu.my
}

\begin{abstract}
The study looked at the level of sustainable development, whether the institutional factors or often, the demographic changes over time, that might have an impact. The data was meticulously collected through 427 returned questionnaires among zakat recipients in eleven districts of Kedah, Malaysia, and it was thoroughly analysed using Partial Least Square - Structural Equation Modelling (PLS-SEM). This study found that the asnaf receives very minimum assistance and that can hardly empower them. Accordingly, it's imperative that the fund needs to be geared towards long term productive use. The results support that the institutional contributory performance (ICP) having a positive effect, and the level of sustainable development of zakat recipients (SDZR) do increase after receiving zakat, but there are issues that need careful addressing. The study further examined the moderating role of demographic factors, such as earnings, age, marital status and gender, and witnessed that after zakat, all parameters improved, though individual moderating variables yet to show any significance. The study initiated a newer dimension through incorporating beforezakat and after-zakat scenarios in examining the comparative impact on SDZR, and likewise understanding the recipient's level of Islamic self-actualisation.
\end{abstract}

Keywords: Zakat recipients, Sustainable development, Balanced scorecard, Islamic selfactualisation.

JEL classification: Q01; I32; M40.

Article history:

Received : October 15, 2020

Revised : August 15, 2021

Accepted : September 10, 2021

Available online : November 30, 2021

https://doi.org/10.21098/jimf.v7i4.1289 


\section{INTRODUCTION}

\subsection{Background}

The study looks into the possibility of findings what are the gaps in the area of sustainable development of zakat recipients (asnafs) through the effective notion of institutional contributory factors. These issues have gained momentum for the Malaysian researchers, because the increment in collection is based on customer's perception of transparent and commendable zakat distribution as well as sustainable management of zakat. According to International Institute for Sustainable Development (IISD), sustainable development (SD) is meeting the needs of the present without compromising the needs of future generations. Particularly, the study intends to understand this scenario in Kedah, Malaysia, because from 2015, the Kedah-zakat (KZ) through enactments became an autonomous body (LZK). Therefore, this requires thorough academic review for two reasons, $1^{\text {st }}, \mathrm{KZ}$ was lagging behind other autonomous zakat bodies (Saad et al., 2016) but $2^{\text {nd }}$, presently it's energised status needs retrospection to analyse the redefined corporatized service-oriented-stakeholder-carer system's functioning towards sustainable achievement of its prime stakeholders, that is, the zakat recipients.

Anis et al. (2016) stated that though collection is progressive, but energising the zakat's distributive effectiveness requires SD of its receivers. And this SD can be achieved 'only' through 'sustained mechanism' in graduating from asking repeated assistance by asnaf, because it can ensure a long-term action-plan. And the primal aim of the concept is to satisfy these recipients presently and into the future. Hence, the study attempts to find whether the SD of zakat recipients (SDZR) in Kedah state of Malaysia (KSM) is linked due to institutional contributory performative (ICP) factors or otherwise, and to detect whether demographic characteristics and its changes, play any form of perceived enhancements. Research showed in Sudan that just cash hand-outs may not work at times, but skills development along with may make a zakat recipient more self-reliant and empowered (Abdelmawla, 2014).

While discussing on service quality SQ, Wahab et al. (2016) raised the issue of often giving 'direct to the receivers' bypassing zakat institutions ZI, which severely challenges the zakat's entire distributive and collective institutional framework, negating the purpose of setting up the organised institutions. Hence as a result, 'only' guaranteeing the excellence in the so called 'service' and the very desired 'quality' (Wahab et al., 2016; 2017) will 'only' and ultimately make these providers and givers of zakat to utilise the right channel in addressing the woes in society through reverting to, as well as appreciating, the institutional (channel and) remedy. Because, according to said authors, the SQ assurance, which is actually 'intrinsic factor towards motivation' may stop 'leakages' in the system and may make the coordination robust and efficient as well as effective. Therefore, only SQ can ensure stakeholders' true satisfaction (Wahab et al., 2017). And this 'customer dimension' is important in both the zakat's receiving and giving ends, as they are intertwined, meaning a happy receiver entices more benevolence among contented givers. Therefore, customer loyalty (Tajuddin et al., 2014) becomes imperative for zakat recipients' sustainable development. Besides, the effectiveness in zakat management depends on providing the necessary zakat amount at the 'very' right time, and likewise receiving the necessary contribution (whether for consumptive 
or productive purposes) from the zakat giver at the 'right' hour, ensuring that the cycle may have a better flow.

Halim et al. (2012) highlight that, the mandate by some zakat authorities ZA to prevent asnaf from turning into a 'recurring asking basket' towards more selfreliance and hence, slowly but steadily becoming productive, is actually a noble vision and likewise an achievable target if implemented carefully. The authors argue that the success factor for the enterprising asnaf is most likely due to commitment, determination, and perseverance.

In addition, the issue of perceptive accountability - plays a role of significance likewise (Buckmaster, 1999). Consequently, the issue of trust, satisfaction, and accountability is expected to drive the ZI towards the SD of asnafs'-welfare (Wahab et al., 2011). So, this sustainable asnaf-development segment is significant for both the zakat givers and the receivers (Haq et al., 2017).

Though the zakat collection as well as distribution trend in Kedah is showing positive (Table 1) in terms of customers' awareness and growth, but researchers are still questioning the reason why the poverty remains a bottleneck in Kedah's developments (Mahamod, 2011). The issue often relates to zakat's institutional capacity (Halimatusa'diyah, 2015) and effective contributory performance (Wahab et al., 2011). In the words of Wahab et al. (2011), "The institution of zakat can also contribute to eradication of poverty (if) effectively implemented".

Table 1

Collection and Distribution of Zakat in Kedah, Malaysia, 2011 to 2018

\begin{tabular}{lccc}
\hline & Collection (RM) & Distribution (RM) & \% Zakat Distribution \\
\hline 2011 & --- & $69,694,487$ & \\
2012 & $100,560,654$ & $84,516,515$ & $84.05 \%$ \\
2013 & $116,656,079$ & $90,543,734$ & $77.62 \%$ \\
2014 & $127,593,807$ & $102,796,615$ & $80.57 \%$ \\
2015 & $133,859,550$ & $133,125,077$ & $99.45 \%$ \\
2016 & $140,448,128$ & $144,831,478$ & $103.12 \%$ \\
2017 & $164,915,431$ & $134,943,608$ & $81.83 \%$ \\
2018 & $177,011,733$ & $150,118,599$ & $84.81 \%$ \\
\hline
\end{tabular}

Source: https://www.zakatkedah.com.my/ RM = Ringgit Malaysia

Furthermore, it may be noted that the famous three pillars of sustainability could include an added pillar, such as Maqasid, in an Islamic framework (Aris et al., 2017; Hasan, 2006; Sarkawi et al., 2015a, 2015b). Therefore, this zakat contribution towards SD of the zakat recipients (SDZR) will encompass more than just mere distributive issue, in understanding the financial as well as the non-financial concerns. Researchers are of the opinion that a performance measurement (PM), together with a performance management system (PMS), is important (Noordin, Haron, \& Kassim, 2017) to address the intricacies of different bottlenecks.

Most importantly, it is widely assumed that the drive towards sustainability will assist the zakat system as well as organisation to effectively strategies the fund timely, orderly, proportionately and systematically to the main recipients. 
Similarly, demographic changes over time, such as earnings, marital status, age, and gender, may all have an impact. Also, understanding the before and after zakat impact on the level of sustainability is long due, therefore assessing accordingly will be a timely initiative.

\subsection{Objective}

The research aims to understand the level of SDZR by addressing institutional factors and zakat's contributory performative mechanism. The study also attempts to understand the moderating factors of the demographic variables, and to assess their effects. The paper outline begins with the background and objective of the study, followed by the literature review and methodology, results and analysis, and finally the conclusion and recommendations.

\section{LITERATURE REVIEW}

Though the sustainability concept has three distinctive aspects but understanding along-with the Islamic-dimension in addition is in fact a positive development for asnaf-welfare. Parenthetically, the institutional factors mostly fall in the category of financial (Alam et al. 2021; Halim et al., 2012), internal rejuvenation (Saad et al., 2016; Wahab et al., 2016), customer perception (Bakar et al., 2010; Wahid et al., 2010, 2011), trust (Abioye et al., 2011), satisfaction (Abioye et al., 2011; Muda et al., 2009; Wahid et al., 2010), learning (Abdelmawla, 2014; Saad et al., 2016), and so on. In zakat literature, the Balanced Scorecard (BSC) concept plays a role, and it was initiated by Norton and Kaplan (1992), and further developed by various researchers, and is broadly seen as a possible remedy in the non-profit sector (NPO) to many of the woes widely found. The discussion on demographic considerations and the characteristics that may have an impacting role in the theoretical relationship have also been accordingly expounded.

\subsection{Sustainable Development (SD)}

Continuing unhindered non-environmental development entails costs which cannot be ignored (Strange et al., 2008). Mere economic prosperity cannot solve societal and environmental issues; therefore, SD, is about integration and understanding of the potential impacts of each action (economic, social and environmental), and more profoundly impacts on the future. The concept evolved worldwide as a renewed yardstick for appreciating human, social and economic development for the utmost safe keep of the fragile environment.

\subsubsection{Sustainability in Islamic Understanding}

In Islam, humans cannot do whatever they wish through free will (Ahmadi, 2016). Humans need to ensure peace and harmony with nature, and need to conform to sustainable understanding, and the relationship with nature in an Islamic worldview, has to be even stricter than conventional wisdom. Therefore, the issue of sustainability is in the core of Islamic-values (Hasan, 2006). 
Al-Mubarak (2016) states that implementation of zakat with maqasid objectives will make the economy stable and sustainable. Ibrahim (2015) elaborates that zakat is a God-gifted system bestowed on mankind to help establish true SD. It is like a 'collective social security scheme for mutual help' as well as sympathy (for the believing asnaf) in an Islamic framework as per the above author. Ariyani (2016) states that zakat is in fact a practical sustainable mechanism to overcome the socioeconomic gaps in Muslim society, while Nurzaman (2011) argues that zakat can ensure strong sustainable poverty alleviation programmes and is a better human development instrument to achieve socio-economic development compared to conventional paradigm.

Islam ordains human as vice-regent on earth (Sarkawi et al., 2015b); therefore, in Islamic framework, human need to follow strict ethical standards and values (Hasan, 2006). This vice-regency role requires human to safely preserve the five essential elements, faith, life, intellect, lineage and property, which is termed the Maqasid-al-Shari'ah (Sarkawi et al., 2015b). Therefore, this effort in an Islamic framework requires self-restraint and epitomising the spiritual self, as part of the vice-regency (Aris et al., 2017; Dusuki \& Bouheraoua, 2011; Hasan, 2006). Furthermore, understanding the three important parts is necessary, namely (i) daruriyat (necessity), (ii) hajiyat (complementarity) and (iii) tahsiniyat (embellishment). Imam Shatibi brought the above five maqasid-essentials into the daruriyat (absolute necessity) group in order to ensure that an Islamic person is a self-actualised Islamic entity who remains upright as a vice-regent on earth (Wardiwiyono, 2013). Accordingly, Dusuki \& Bouheraoua (2011) argue that to achieve the ultimate Tahsiniyat is like achieving the ultimate in self-actualisation in an Islamic framework.

As per Kamali (2011), in pursuing Shariatic-goals under the auspices of Maqasid, there are three main objectives that can be attained, i.e. mercy of mankind, benefits to greater nature and all the species, and removing any harm, in other words, ensuring public benefit (Maslahah for Ummah). In Islam, Maslahah aims to protect humans, society and the fragile nature, which are the three main elements of conventional understanding of sustainability. Imam Ghazzali rightly explained that to protect the religion or belief (hifzu Deen), there are four Duniyawi (worldly) activities that are important, namely the protection of life (nafs), lineage (nasl), intellect ('aql), and wealth (maal) (Abubakar, 2016).

In understanding sustainability, it is important to assess hardship through the issue of lack of health, lack of education, their coping with risks and vulnerability, powerlessness or social exclusion (Ahmed, Johari, \& Abdul Wahab, 2017). So allocating the zakat has to improve that status quo.

\subsection{Issues Encompassing the Institutional Factors in Zakat}

According to MacKrell, Houghton, \& Campbell (2011) the BSC could be best suited to augment the issues in NPOs. In developing a PMS in zakat, Taha, Ali, Embong, \& Nor (2014) and Zulkifli, Taha, \& Embong (2014) categorised the importance of the BSC, along with the religious perspective in the framework. In the same way, Zulkifli et al. (2014) assessed the level of asnaf satisfaction while analysing the distributive issues in zakat and their repercussions. 


\subsubsection{Financial Effectiveness}

Islam places zakat at the forefront in addressing the issue of socioeconomic welfare (Ibrahim \& Ghazali, 2014). It has no institutional collateral clause; therefore, freeing from debt through capital transfer is encouraged in Islam (Qur'an 9:60). In this way, zakat can be a healthy counter strategy to all usurious mechanisms in society. Furthermore, it is similar to an informal Islamic banking system, in which elements of interest will be almost zero. Therefore, this will augment zakat's institutional contribution and development.

Besides, savings is subject to zakat deductions (Hassan, 1987); therefore, all savings need to be invested in productive or circulation modes. Hence, keeping a proportion of the zakat fund for able bodied, trained and skilled asnaf is ideal. The target to take them out of the 'asking basket', and turn them into sahib-e-nisab (giver of zakat) through guidance and support, would be a great achievement. On consumption front, injections into the poorer sector can boost the economy, which will have a multiplier effect. In addition, zakat can also be a monetary instrument for regulating inflation through the supply and demand of money (Hassan, 1987; Sarea, 2012). Consistently, zakat can bridge the resource gap in society (Hashem \& El-sha'er, 2015).

ZIs need to consider the right steps forward in terms of assistance, planning, strategising, executing, monitoring and budgeting for empowerment plans. This requires harmonisation of the SDZR. Unfortunately, the failure rate in asnaf empowerment strategy is way too high (Said et al., 2014, p.126). However, selfrespect is important and only that will drive productivity and eventually the community's burden will ease (Senadjki \& Sulaiman, 2015). The Almighty Lord commanded, "And help one another in goodness and piety..." (Qur'an 5:2).

\subsubsection{Customer and Internal Effectiveness}

Zulkifli et al. (2014) conducted crucial research on recognising the core causes of the ineffectiveness of the zakat institutional contributory system for asnafs' SD and addressed the issues through the BSC framework. They identify the dissatisfaction in the distributive mechanism, and hence suggest that to overcome zakat's contributory issues, the system needs to adopt a healthier approach in terms of customer transparency and accountability processes, amongst others. In addition, the study highlighted the issue of huge zakat fund each year that is left despondently undistributed. However, the increase in religiosity awareness and the sense of self-satisfaction (in giving) amongst believers, over the years, is commendable.

According to Ali et al. (2013), just as pruning a plant increases its productivity, zakat contributions will increase a believer's wealth and ultimately that of the nation. In the same manner, building trust in ZIs is becoming important (Abioye, Mohamad, \& Adnan, 2013). Mohsin \& Ismail (2013) explain that if the intention to pay zakat is present, then the tax rebate mechanism through the salary deduction scheme (SDS) is a very noteworthy initiative and a relief for the givers. 


\subsubsection{Learning and Growth Issues in Zakat}

To overcome the poverty and hardship, ZI requires to focus on intellectual capital development (Adnan et al., 2013). Likewise, Hassan (1987) opines that the knowledge and training has to be the top-most priority by the ZI. Author recommends, autonomy in ZI is vital, but the policies need to be a coherent one. Next, the issue of credibility remains paramount. To end with, lack of adequate knowledge can lead to improper zakat jurisdiction on zakat givers, which may drive away the capacity of implementing zakat as a noble cause.

Abdelmawla (2014) made a study in Sudan in which the education sector played a complementary role, along with zakat development. In the study, Abdelmawla shows that in fact educational-attainment leads to a decrease in hardship in a far better way than just mere financial assistance.

Conclusively, SDZR was chosen as the dependent or endogenous variable for this study, because understanding this is vital in today's zakat development, as it can indicate the true level of recipients' welfare. The SDZR in this study encompasses economic, social, environmental and Islamic self-actualisation (ISA) aspects. Therefore, on the exogenous or independent side, there are (i) financial, (ii) customer, (iii) internal, (iv) learning and growth - the four important variables that will assess the ICP and its impact on SDZR.

\subsubsection{Incorporation of Sustainability into the BSC Framework}

Petrini \& Pozzebon (2009) advanced the sustainable BSC (SBSC) concept for future organisational strategic management. In support of the SBSC framework for the non-profit sector, MacKrell et al. (2011), citing Bieker (2003, p.2), stated that SBSC offers a focus on the accomplishment of strategic goals and targets in the future (leading indicators), as well as results (lagging indicators) to represent the effectiveness and efficiency of measures in the past. An organisation's sustainability agenda will most likely limit it from jeopardising the future, while seeking current unbridled expansion. This will also seek a balance in economic, social and environmental requirements and will probably gear the strategic initiatives towards a more holistic evolvement.

\subsection{Importance of Demographic Characteristics}

In recent studies, gender as a determinant factor has been gaining momentum. Furthermore, demographic variables as moderating vectors are well-documented (Rudito, 2010). Correspondingly, gender and age have been adapted as predictors in different studies (Price, 2011). Similarly, demographic characteristics are gaining wider acceptability in analytical frameworks (Akram et al., 2016; Bierman, 2012; Henrique \& De Matos, 2015; Memon et al., 2019). Hence, this study aims to understand the moderation effect of age, gender, marital status and earnings on the SDZR in KSM. 


\subsection{Underlying Theory}

It is considered that the stakeholder theory is best justified in addressing the relationship and the interconnectedness between the variables in explaining the directions. Steurer, Langer, Konrad, \& Martinuzzi (2005) highlight that organisations can achieve sustainable goals only by addressing stakeholders' concerns. Kaplan (2009) clearly demonstrates that "PM design starts with stakeholders", citing Neely, Adams, \& Kennerley (2002).

Waddock \& Graves (1997) highlight that the present day challenging expectations from stakeholders and the recuperating importance of environmental concerns influence the strategic decisions in most modern institutions, referring to Prahalad \& Hamel (1994). In this vein, Waddock \& Graves state that the level of social investments in the modern age alone was more than $\$ 650$ billion, reporting in 1997. Furthermore, Hubbard (2009) in explaining the stakeholder theory, clarified that, the sustainability induced balanced scorecard (SBSC) is linked beyond just mere triple bottom line TBL or the BSC concept alone, because the measures in the process addresses all the stakes in the firm, i.e., the internal as well as the external factors, and the TBL is also based on the stakeholder theory.

In Islamic research, stakeholder care is prioritised (Said et al., 2011), along with understanding the importance of organisational learning. Mohammad (2015), addressing the need for transparent zakat disclosure, state that giving importance to stakeholders is an overriding issue. This is because ZIs need to provide the stakeholders - just, knowledgeable information about their operations and ensure sustainable and effective management of the zakat funds to guarantee the sustainable development of asnafs' welfare (Zainal, Bakar, \& Saad, 2016). Finally, Khalili (2011) clarifies that the importance of sustainability is growing, but the concept requires setting the priorities, defining the principles, and the formation of strategies for continuous development.

\section{METHODOLOGY}

This research aims to comprehend the sustainable development of the zakat recipients in KSM. The institutional contributory performance (ICP) of zakat will be measured by the four independent or exogenous variables, (i) customer, (ii) internal, (iii) learning and growth, together with (iv) financial effectiveness. The study assumes that the demographic changes likewise can considerably influence the sustainable development issues, and at times may impact the relationships, as seen in few research findings (Homburg \& Giering, 2001). The sustainable development normally has three pillars in a conventional framework, but in an Islamic-framework, the three pillars may not be all-encompassing (Hasan, 2006), therefore ISA that will be measured by the Maqasid, is included. The ISA is in fact inspired by the decisive work carried out by Dusuki \& Bouheraoua (2011), as well as from the understanding from the effort done by Aris et al. (2017). Therefore, the endogenous or dependent variable - is the SDZR, which will encompass the following, social, economic, environment and ISA. The framework is presented in Figure 1. 


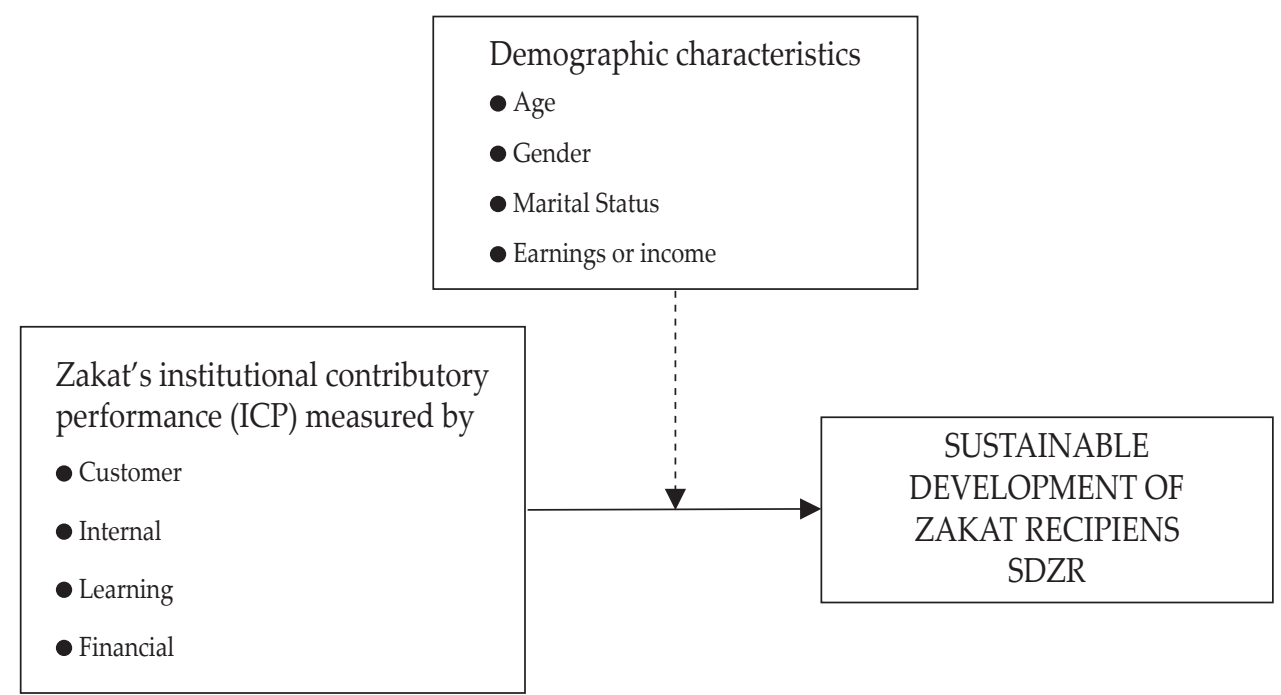

Figure 1.

Research Framework

\subsection{Model Development}

The proposed hypotheses are as follows:

H1 There is statistically significant impact of zakat's ICP on the level of SDZR in KSM.

H1.1 Customer welfare is statistically significantly related to the level of SDZR in KSM.

H1.2 Financial wellbeing is statistically significantly related to the level of SDZR in KSM.

H1.3 Internal system wellbeing is statistically significantly related to the level of SDZR in KSM.

H1.4 Learning and knowledge sharing is statistically significantly related to the level of SDZR in KSM.

H2 There is a statistically significant moderating effect of demographic characteristics (such as age, earnings, marital status, and gender) on the relationship between the institutional (ICP) and the SDZR in KSM (where age $=\mathrm{H} 2.1$, earnings $=\mathrm{H} 2.2$, marital status $=\mathrm{H} 2.3$, gender $=\mathrm{H} 2.4$ )

H3. There is statistically significant difference between the level of SDZR in KSM with regard to ICP before and after zakat assistance.

The theoretical model in the study is based on stakeholder theory; therefore, the survival of an entity lies simply in treasuring and addressing all the entities, that is all the stakeholders. After setting the hypotheses, it is important to focus on the questionnaire, because this is necessary to collect the necessary data for the quantitative analysis. The questionnaire was adapted to some extent from Asri (2011), Dusuki \& Bouheraoua (2011), Kamaruddin \& Samsudin (2014), Kaplan (2001), Sarkawi et al. (2015a, 2015b), Senadjki et al. (2015), Taha et al. (2014) and 
Zulkifli et al. (2014). The aim of this study is to obtain fully impartial and overall feedback on the performance of zakat management by asking the receivers of zakat, the relevant and precise questions to obtain the maximum feedback. The overall study construct will be measured by a five-point Likert scale.

\subsection{Data}

The sample provides the researcher to draw conclusions that are generalisable of the population. The sample was selected from asnafs in KSM. The zakat recipients of Kedah are the population (around 65,000) of the study. 427 samples were collected from zakat recipients who were surveyed through the stratified random sampling method. This type of sampling can be administered when samples are taken from identifiable groups or strata (Bougie \& Sekaran, 2016). According to Saunders, Lewis, \& Thornhill (2007), a sample size of 384 would be sufficient for any large population. This study will follow the above recommendation for the justification of the sample size. The units of analysis in the study are the recipients of the ZI in KSM.

According to Sekaran (2003), data can be acquired either from primary or secondary sources. Primary data enable the researcher to contribute to the body of knowledge (Kothari, 2009). Therefore, the data collected for this study can be an original and additional resource in the literature. The survey method is best suited for this study, as a maximum response rate is only possible through a survey, as stated by Bougie \& Sekaran (2016). The study adopted personally administered questionnaire survey method to ensure high response rate is attained within a given time.

\subsection{Method}

To analyse the data, descriptive statistics and inferential data analysis techniques were employed. First, screening of the data is important, followed by analysis of the descriptive statistics, including factor and reliability analysis. The research uses PLS SEM because according to Muhammad \& Saad (2016), this is sufficient for examining a complete model and for estimation of the causal relationships between complex concepts (Akter, D'Ambra, \& Ray, 2011). Therefore, in line with Akter et al. (2011), PLS-SEM is the dominant method for establishing a rigor in complex models.

For this research, a pilot study was conducted in two steps in order to achieve greater validity and reliability from the respondents. In the first step, pretesting helped to understand the content validity, as many measurement items were modified from previous relevant research. In the second step, pilot research was done to derive at results. The results of reliability test conducted on the respondents in regard to - before and after the zakat-assistance. All the variables were reported to have acceptable reliability values above 0.7, which according to Nunally (1978), as cited by Ponterotto \& Ruckdeschel (2007), adequate in social sciences. 


\section{RESULTS AND ANALYSIS}

\subsection{Demographic Analysis}

The data is collected through a structured questionnaire survey from eleven zones of KSM. The descriptive data is shown in Table 2 . Closely $68.3 \%$ are below age of 60 , it means that nearly $3 / 4$ of the respondents are in the active-age for empowering themselves. Furthermore, nearly $89 \%$ having considerable level of education. And out of total respondents, more than half is new zakat applicant, and that signifies - new bracket of hardship that is possibly rising. Besides, not employed is nearly $40 \%$, and having no plan at all for the future, is nearly $55 \%$, which requires policy and strategic adjustments in terms of educational prioritisation, empowerment, enlightening them with long term vision and upliftment. And nearly $74.7 \%$ of the seekers are getting just mere RM 500 or less, from the ZI. And combined income of RM 1000 or less per month, per seeking household, is about $80.5 \%$, which signifies that the effort of sustainable living and proactive empowerment programme needs a true kick-start in the near future. And the hardship is rising due to inadequate matching level of education and employment, and moreover this mismatch can give rise to no-focus-or-plan, and due to resultant worsening of circumstances of their fate, forcing many of them to seek easy zakat assistance and work less.

Table 2.

Sample Profile

\begin{tabular}{|c|c|c|c|c|c|c|c|c|}
\hline Variable & Value & $\%$ & Variable & Value & $\%$ & Variable & Value & $\%$ \\
\hline \multirow{4}{*}{ Gender } & Male & 47.5 & \multirow{6}{*}{ Education } & $\begin{array}{c}\text { No } \\
\text { education }\end{array}$ & 11.0 & \multirow{5}{*}{$\begin{array}{c}\text { Household } \\
\text { Y }\end{array}$} & 0 to 500 & 43.3 \\
\hline & Fomolo & 525 & & Primary & 45.4 & & 501 to 1000 & 37.2 \\
\hline & remale & 52.5 & & Secondary & 41.0 & & 1001 to 1500 & 15.9 \\
\hline & $20-39$ & 11.2 & & Certificate & 1.6 & & 1501 to 2000 & 2.3 \\
\hline \multirow[t]{3}{*}{ Age } & $40-60$ & 57.1 & & Diploma & 0.5 & & $\begin{array}{l}\text { More than } \\
2000\end{array}$ & 1.2 \\
\hline & Above 60 & 31.6 & & Degree & 0.5 & \multirow{6}{*}{$\begin{array}{c}\text { Household } \\
\text { Z }\end{array}$} & & \\
\hline & & & Y Members & 1 or fewer & 77.5 & & 0 to 500 & 74.7 \\
\hline \multirow{4}{*}{$\begin{array}{l}\text { Marital } \\
\text { Status }\end{array}$} & Married & 60.9 & & 2 & 15.9 & & 501 to 1000 & 19.7 \\
\hline & $\begin{array}{l}\text { Widow/ } \\
\text { Divorced }\end{array}$ & 34.2 & & 3 & 4.9 & & 1001 to 1500 & 5.2 \\
\hline & Single & 4.9 & & 4 & 1.2 & & 1501 to 2000 & 0.2 \\
\hline & & & & 5 and above & 0.5 & & $\begin{array}{l}\text { More than } \\
2000\end{array}$ & 0.2 \\
\hline \multirow[t]{5}{*}{ Profession } & Employed & 30.68 & & & & \multirow{5}{*}{ Plan } & & \\
\hline & $\begin{array}{c}\text { Self- } \\
\text { employed }\end{array}$ & 22.71 & & & & & Short-term & 14.05 \\
\hline & $\begin{array}{c}\text { Not } \\
\text { employed }\end{array}$ & 39.81 & & & & & $\begin{array}{l}\text { Medium- } \\
\text { term }\end{array}$ & 28.10 \\
\hline & Farming & 1.87 & & & & & Long-term & 2.58 \\
\hline & $\begin{array}{c}\text { Retirees \& } \\
\text { Others }\end{array}$ & 4.91 & & & & & No Plan & 55.26 \\
\hline
\end{tabular}

Note: $\mathrm{Y}$ stands for earning and $\mathrm{Z}$ for zakat, and it is monthly income in both $\mathrm{Y}$ and $\mathrm{Z}$. 
In Table 3, it is clear that the living-cost allowances (nearly 50\%) are the main priority in the case of Kedah-zakat, but for entrepreneurial development there is meagre support, just below $1 \%$. Though for educational development, support is at nearly $28 \%$, but from Table 2 it can be seen that the educational incentives may not be properly working to lift the seekers and receivers of zakat to be out of the asking basket syndrome, which is really worrisome in the foreseeable future.

Table 3.

Zakat amounts distributed from January to August 2018 (KSM)

\begin{tabular}{lcc}
\hline Sector & Amount (Millions) & $\%$ \\
\hline Living-cost allowance & 42.00 & 49.16 \\
Medical allowance & 2.70 & 3.16 \\
Entrepreneurial development & 0.84 & 0.98 \\
Housing & 0.70 & 0.82 \\
Education development & 24.00 & 28.08 \\
Disaster relief & 1.20 & 1.40 \\
Asnaf-development & 14.00 & 16.39 \\
\hline Total zakat givers 65,149* & Total zakat receivers 65,149 \\
Total amount received RM 118,614,562.17 & \multicolumn{2}{c}{ Fi Sabillah 57.59\% } \\
Total amount distributed RM 117,305,560.09 & Miskin 42 \%; Rest < $\%$ \\
*as reported up to August 2018 by Kedah-Zakat & \multicolumn{2}{c}{}
\end{tabular}

\subsection{Evaluation of PLS Measurement and Structural Results in the Before and After Zakat Scenarios}

After screening the data, it is important to assess the outer and inner models, as per PLS-SEM rules (Hair, Sarstedt, Pieper, \& Ringle, 2012). The primary objective of PLS-SEM is to estimate the latent variable scores, which maximises the explained variance of the endogenous latent constructs in the path model (Avkiran, 2018). Therefore, the outer or measurement model requires assessment of the reliability and validity of the model, in order to gauge the consistency, as per the above author. In reality, the measurement model needs to be evaluated before testing the structural model (Koufteros, 1999).

In this study, confirmatory factor analysis was performed with a repeated indicator approach, as prescribed by PLS-SEM rules. According to Chuah et al. (2017), the benefits of this approach are in its ability to estimate all the indicators in the lower as well as higher order constructs concurrently, thus avoiding interpretational issues later.

According to Alarcón, Sánchez, \& De Olavide (2015), the convergent validity of the measurement model can be assessed by average variance extracted (AVE) and composite reliability (CR). Through CR, PLS-SEM can demonstrate different indicator reliabilities, while avoiding underestimation issues. According to Hair, Sarstedt, Hopkins, \& Kuppelwieser (2014), satisfactory construct reliability will be attained when the composite reliability index is 0.70 or higher. In effect, validity is concerned with how well the concept is defined by the measures (Hair et al., 2014). In Tables 4 and 5 and Figures 2 and 3, the factor loadings are mostly at the higher end, which demonstrates that the measures have achieved convergent validity. 
Table 4.

Convergent Validity of the First Order Constructs (Before Zakat)

\begin{tabular}{|c|c|c|c|c|c|}
\hline Construct & Item & Loading & $\begin{array}{c}\text { Cronbach's } \\
\text { Alpha }\end{array}$ & CR & AVE \\
\hline \multirow[t]{6}{*}{ Financial Effectiveness } & FE1 & 0.848 & 0.892 & 0.919 & 0.655 \\
\hline & FE2 & 0.820 & & & \\
\hline & FE3 & 0.867 & & & \\
\hline & FE4 & 0.882 & & & \\
\hline & FE5 & 0.771 & & & \\
\hline & FE6 & 0.643 & & & \\
\hline \multirow[t]{6}{*}{ Customer Effectiveness } & CE1 & 0.812 & 0.860 & 0.897 & 0.595 \\
\hline & CE2 & 0.836 & & & \\
\hline & CE3 & 0.799 & & & \\
\hline & CE4 & 0.823 & & & \\
\hline & CE5 & 0.735 & & & \\
\hline & CE6 & 0.595 & & & \\
\hline \multirow[t]{6}{*}{ Internal Effectiveness } & IE1 & 0.770 & 0.847 & 0.888 & 0.573 \\
\hline & IE2 & 0.739 & & & \\
\hline & IE3 & 0.597 & & & \\
\hline & IE4 & 0.694 & & & \\
\hline & IE5 & 0.863 & & & \\
\hline & IE6 & 0.848 & & & \\
\hline \multirow{6}{*}{$\begin{array}{l}\text { Learning Growth } \\
\text { Effectiveness }\end{array}$} & LGE1 & 0.688 & 0.877 & 0.907 & 0.621 \\
\hline & LGE2 & 0.751 & & & \\
\hline & LGE3 & 0.851 & & & \\
\hline & LGE4 & 0.808 & & & \\
\hline & LGE5 & 0.800 & & & \\
\hline & LGE6 & 0.820 & & & \\
\hline \multirow[t]{4}{*}{ Economic Factor } & EF1_B & 0.828 & 0.858 & 0.870 & 0.635 \\
\hline & $\mathrm{EF} 2 \mathrm{~B}$ & 0.912 & & & \\
\hline & EF3_B & 0.867 & & & \\
\hline & EF5_B & 0.519 & & & \\
\hline \multirow[t]{5}{*}{ Social Factor } & SF2_B & 0.561 & 0.821 & 0.875 & 0.589 \\
\hline & SF3_B & 0.710 & & & \\
\hline & SF4_B & 0.851 & & & \\
\hline & SF5_B & 0.872 & & & \\
\hline & SF6_B & 0.799 & & & \\
\hline \multirow[t]{6}{*}{ Environmental Factor } & EVF1_B & 0.636 & 0.897 & 0.923 & 0.670 \\
\hline & EVF2_B & 0.845 & & & \\
\hline & EVF3 B & 0.740 & & & \\
\hline & EVF4_B & 0.863 & & & \\
\hline & EVF5_B & 0.905 & & & \\
\hline & EVF6_B & 0.888 & & & \\
\hline \multirow[t]{14}{*}{ Islamic Self-Actualisation } & ISA1_B & 0.648 & 0.926 & 0.936 & 0.513 \\
\hline & ISA4_B & 0.737 & & & \\
\hline & ISA5_B & 0.749 & & & \\
\hline & ISA6_B & 0.735 & & & \\
\hline & ISA9-B & 0.732 & & & \\
\hline & ISA10_B & 0.667 & & & \\
\hline & ISA12_B & 0.667 & & & \\
\hline & ISA13_B & 0.713 & & & \\
\hline & ISA14_B & 0.755 & & & \\
\hline & ISA15_B & 0.621 & & & \\
\hline & ISA16_B & 0.802 & & & \\
\hline & ISA17_B & 0.690 & & & \\
\hline & ISA18_B & 0.737 & & & \\
\hline & ISA19_B & 0.754 & & & \\
\hline
\end{tabular}

Note: ISA_B= Islamic self-actualisation before zakat 


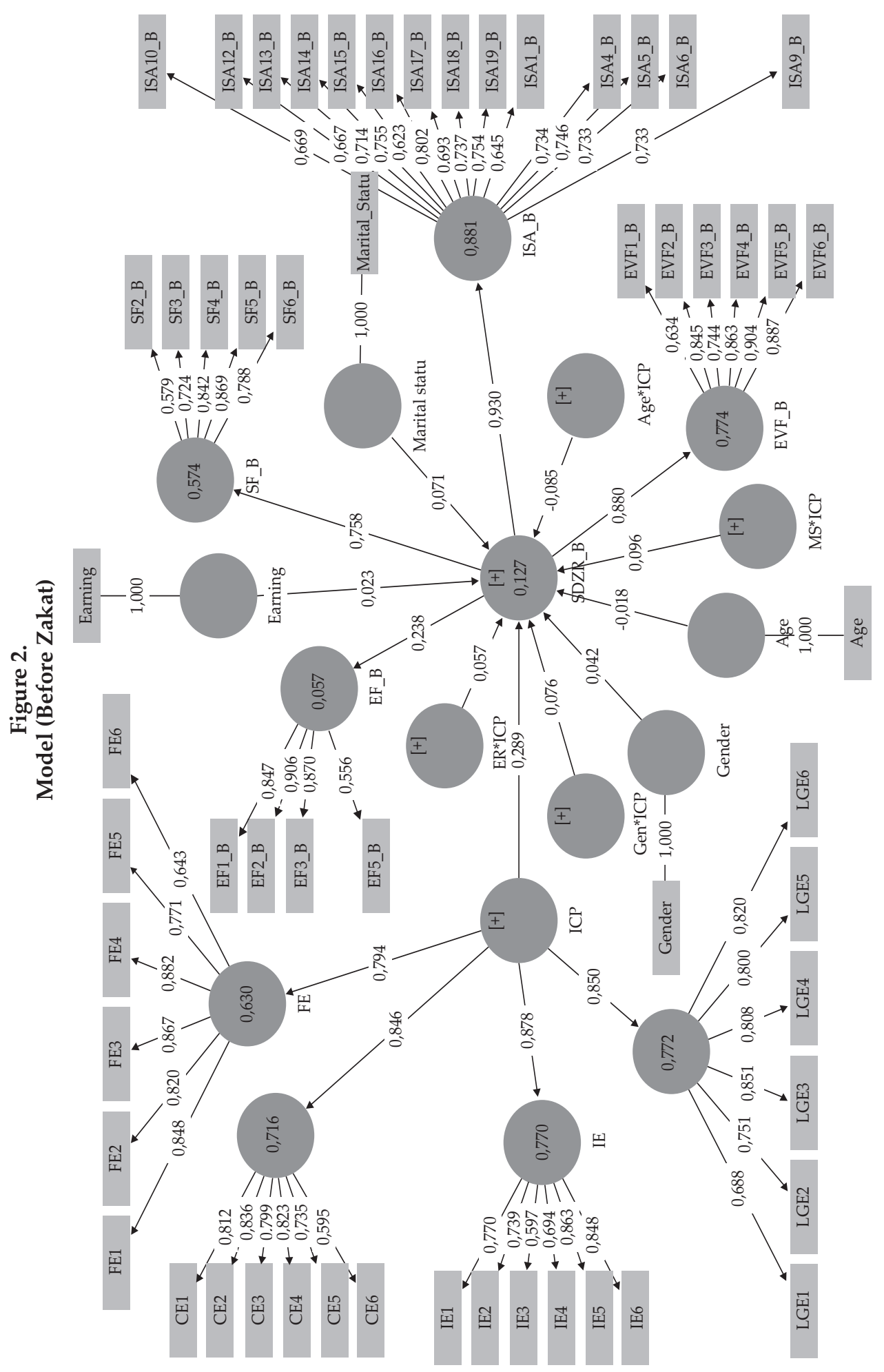


Table 5.

Convergent Validity of the First Order Constructs (After Zakat)

\begin{tabular}{|c|c|c|c|c|c|}
\hline Construct & Items & Loadings & $\begin{array}{c}\text { Cronbach's } \\
\text { Alpha }\end{array}$ & CR & AVE \\
\hline \multirow{6}{*}{ Financial Effectiveness } & FE1 & 0.815 & 0.928 & 0.943 & 0.736 \\
\hline & FE2 & 0.890 & & & \\
\hline & FE3 & 0.886 & & & \\
\hline & FE4 & 0.853 & & & \\
\hline & FE5 & 0.854 & & & \\
\hline & FE6 & 0.846 & & & \\
\hline \multirow[t]{6}{*}{ Customer Effectiveness } & CE1 & 0.881 & 0.919 & 0.937 & 0.713 \\
\hline & CE2 & 0.890 & & & \\
\hline & CE3 & 0.885 & & & \\
\hline & CE4 & 0.735 & & & \\
\hline & CE5 & 0.875 & & & \\
\hline & CE6 & 0.788 & & & \\
\hline \multirow[t]{6}{*}{ Internal Effectiveness } & IE1 & 0.648 & 0.905 & 0.928 & 0.683 \\
\hline & IE2 & 0.819 & & & \\
\hline & IE3 & 0.870 & & & \\
\hline & IE4 & 0.886 & & & \\
\hline & IE5 & 0.858 & & & \\
\hline & IE6 & 0.854 & & & \\
\hline \multirow[t]{6}{*}{ Learning Growth Effectiveness } & LGE1 & 0.790 & 0.871 & 0.900 & 0.600 \\
\hline & LGE2 & 0.833 & & & \\
\hline & LGE3 & 0.756 & & & \\
\hline & LGE4 & 0.766 & & & \\
\hline & LGE5 & 0.725 & & & \\
\hline & LGE6 & 0.776 & & & \\
\hline \multirow[t]{6}{*}{ Economic Factor } & EF1_A & 0.633 & 0.871 & 0.904 & 0.614 \\
\hline & EF2_A & 0.713 & & & \\
\hline & EF3_A & 0.832 & & & \\
\hline & EF4_A & 0.858 & & & \\
\hline & EF5_A & 0.796 & & & \\
\hline & EF6_A & 0.882 & & & \\
\hline \multirow[t]{6}{*}{ Social Factor } & SF1_A & 0.882 & 0.934 & 0.949 & 0.756 \\
\hline & SF2_A & 0.767 & & & \\
\hline & SF3_A & 0.874 & & & \\
\hline & SF4_A & 0.920 & & & \\
\hline & SF5_A & 0.902 & & & \\
\hline & SF6_A & 0.861 & & & \\
\hline \multirow[t]{6}{*}{ Environmental Factor } & EVF1_A & 0.836 & 0.905 & 0.928 & 0.684 \\
\hline & EVF2_A & 0.863 & & & \\
\hline & EVF3_A & 0.900 & & & \\
\hline & EVF4_A & 0.858 & & & \\
\hline & EVF5_A & 0.824 & & & \\
\hline & EVF6_A & 0.657 & & & \\
\hline
\end{tabular}


Table 5.

(After Zakat) (continued)

\begin{tabular}{|c|c|c|c|c|c|}
\hline Construct & Items & Loadings & $\begin{array}{c}\text { Cronbach's } \\
\text { Alpha }\end{array}$ & CR & AVE \\
\hline \multirow[t]{15}{*}{ Islamic Self-Actualisation } & ISA2_A & 0.667 & 0.931 & 0.940 & 0.512 \\
\hline & ISA3_A & 0.661 & & & \\
\hline & ISA5_A & 0.702 & & & \\
\hline & ISA6_A & 0.760 & & & \\
\hline & ISA7_A & 0.788 & & & \\
\hline & ISA8_A & 0.577 & & & \\
\hline & ISA9_A & 0.792 & & & \\
\hline & ISA10_A & 0.757 & & & \\
\hline & ISA11_A & 0.731 & & & \\
\hline & ISA12_A & 0.785 & & & \\
\hline & ISA13_A & 0.710 & & & \\
\hline & ISA14_A & 0.735 & & & \\
\hline & ISA15_A & 0.700 & & & \\
\hline & ISA16_A & 0.744 & & & \\
\hline & ISA18_A & 0.582 & & & \\
\hline
\end{tabular}

ISA_A= Islamic self-actualisation after zakat 


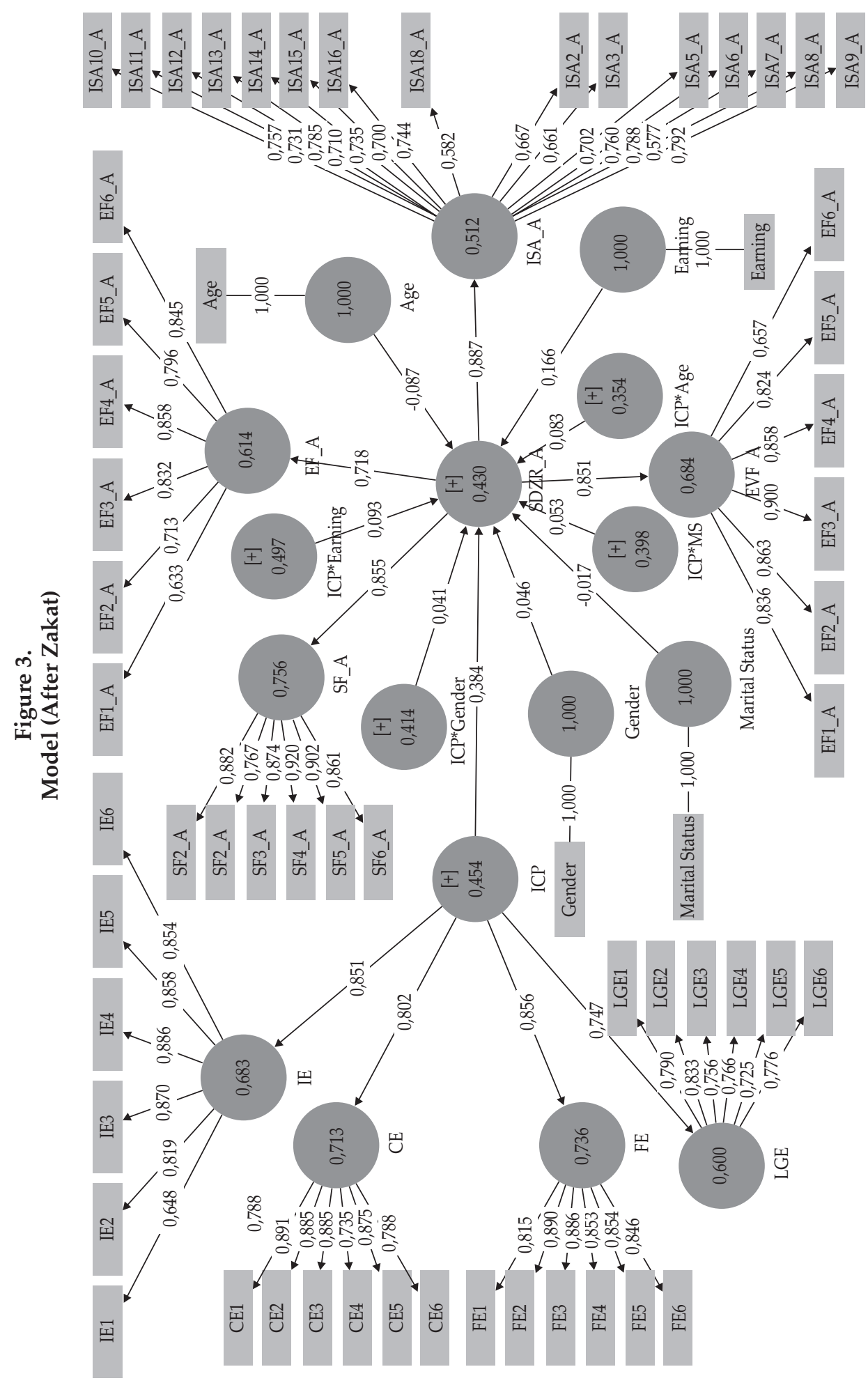




\subsection{Convergent Validity of the Second Order Construct}

Confirmatory factor analysis was performed with a repeated indicator approach for the second order construct of SDZR in the before-zakat and after-zakat scenarios (Tables 6 and 7). Resultantly, all the factor loadings are much above 0.5, suggesting better convergent validity. The Cronbach's $\alpha$, composite-reliability, are above 0.7 and that signifies internal-consistency. The AVE is also above 0.5, again demonstrating convergent validity (Parihar, Dawra, \& Sahay, 2019).

Table 6.

Convergent Validity of the Second Order Construct (Before Zakat)

\begin{tabular}{lccccc}
\hline $\begin{array}{l}\text { Second } \\
\text { order } \\
\text { construct }\end{array}$ & First order construct & Loading & $\begin{array}{c}\text { Cronbach's } \\
\text { Alpha }\end{array}$ & CR & AVE \\
\hline SDZR_B & Economic Factor & $0.811^{* * *}$ & 0.961 & 0.963 & 0.665 \\
& $\quad$ Social Factor & $0.784^{* * *}$ & & & \\
& Environmental Factor & $0.735^{* * *}$ & & & \\
& Islamic Self-Actualisation & $0.921^{* * *}$ & & & \\
\hline
\end{tabular}

Note: ${ }^{* * *}$ significant at the .001 level. SDZR_B = sustainable development of zakat recipients before zakat

Table 7.

Convergent Validity of the Second Order Construct (After Zakat)

\begin{tabular}{lccccc}
\hline $\begin{array}{l}\text { Second order } \\
\text { construct }\end{array}$ & First order construct & Loading & $\begin{array}{c}\text { Cronbach's } \\
\text { Alpha }\end{array}$ & CR & AVE \\
\hline SDZR_A & Economic Factor & $0.719^{* * *}$ & 0.957 & 0.961 & 0.690 \\
& Social Factor & $0.857^{* * *}$ & & & \\
& Environmental Factor & $0.852^{* * *}$ & & & \\
& Islamic Self-Actualisation & $0.884^{* * *}$ & & & \\
\hline
\end{tabular}

Note: ${ }^{* * *}$ significant at .001 Note: SDZR_A = sustainable development of zakat recipients after zakat

\subsection{Inner Model Evaluation}

Once the reliability and validity of the outer model is established, steps are required to validate the hypothesised relationships within the inner model (Hair et al., 2014). In reality, by measuring higher order constructs, Hair, Ringle, \& Sarstedt (2013) suggest that it helps to reduce the number of relationships in the PLS path model. Therefore, through PLS-SEM, the sample data will assist the parameters to predict the endogenous constructs. Hence, for assessment in the PLS regiment, it is important to establish the coefficient of determination, the effect size and the cross-validated redundancy.

\subsubsection{Path Coefficients}

In the structural assessments below, the path analyses are done to test the hypotheses whether they are supported or otherwise. In Table 8 below (beforezakat scenario), it is obvious that internal-effectiveness and learning-and-growtheffectiveness are supported as can be observed from the confidence interval and $p$ 
values (IE -> SDZR_B, $\beta=0.133, t=1.984, p=0.047$; LGE $->$ SDZR_B, $\beta=0.270, t=$ $5.122, \mathrm{p}=0.000$ ). Whereas in Table 9 below (after-zakat scenario), it is the customer and financial effectiveness that is resounding, as those hypotheses are supported (CE -> SDZR_A, $\beta=0.198, t=2.727, p=0.006$; FE $->$ SDZR_A, $\beta=0.216, t=3.332$, $\mathrm{p}=0.001)$.

Table 8.

Path Coefficients (Before Zakat)

\begin{tabular}{|c|c|c|c|c|c|c|c|c|}
\hline \multirow{2}{*}{ Hs } & \multirow{2}{*}{ Relationship } & \multirow{2}{*}{ Beta } & \multirow{2}{*}{ SE } & \multirow{2}{*}{$t$ value } & \multirow{2}{*}{$p$ value } & \multirow{2}{*}{ Decision } & \multicolumn{2}{|c|}{ CI (BC) } \\
\hline & & & & & & & LL & UL \\
\hline H1.1B & CE -> SDZR_B & 0.125 & 0.064 & 1.961 & 0.050 & $\begin{array}{c}\text { Not } \\
\text { supported }\end{array}$ & -0.001 & 0.246 \\
\hline H1.2B & FE -> SDZR_B & 0.120 & 0.064 & 1.882 & 0.060 & $\begin{array}{c}\text { Not } \\
\text { supported }\end{array}$ & -0.007 & 0.241 \\
\hline H1.3B & IE -> SDZR_B & 0.133 & 0.067 & 1.984 & 0.047 & Supported & 0.003 & 0.265 \\
\hline $\mathrm{H} 1.4 \mathrm{~B}$ & LGE $->$ SDZR_B & 0.270 & 0.053 & 5.122 & 0.000 & Supported & 0.162 & 0.368 \\
\hline
\end{tabular}

Note: Hs = hypotheses, CI (BC) = confidence interval (bias corrected), LL = lower limit, UL = upper limit,

$\mathrm{FE}=$ financial effectiveness, $\mathrm{CE}=$ customer effectiveness, IE = internal effectiveness, $\mathrm{LGE}=$ learning and growth effectiveness, SDZR_B = sustainable development of zakat recipients before zakat, B = before zakat

Table 9.

Path Coefficients (After Zakat)

\begin{tabular}{lcccccccc}
\hline \multirow{2}{*}{ Hs } & \multirow{2}{*}{ Relationship } & \multirow{2}{*}{ Beta } & \multirow{2}{*}{ SE } & \multirow{2}{*}{ value } & $\begin{array}{c}\text { P - } \\
\text { Values }\end{array}$ & Decision & \multicolumn{2}{c}{ CI (BC) } \\
\hline H1.1A & CE -> SDZR_A & 0.198 & 0.072 & 2.727 & 0.006 & Supported & 0.049 & 0.336 \\
H1.2A & FE -> SDZR_A & 0.216 & 0.065 & 3.332 & 0.001 & Supported & 0.091 & 0.344 \\
H1.3A & IE -> SDZR_A & 0.107 & 0.064 & 1.656 & 0.098 & $\begin{array}{c}\text { Not } \\
\text { supported }\end{array}$ & -0.023 & 0.232 \\
H1.4A & LGE -> SDZR_A & -0.048 & 0.06 & 0.791 & 0.429 & $\begin{array}{c}\text { Not } \\
\text { supported }\end{array}$ & -0.182 & 0.055 \\
\hline
\end{tabular}

Note: Hs = hypotheses, CI (BC) = confidence interval (bias corrected), LL = lower limit, UL = upper limit

$\mathrm{FE}=$ financial effectiveness, $\mathrm{CE}=$ customer effectiveness, $\mathrm{IE}=$ internal effectiveness, $\mathrm{LGE}=\mathrm{learning}$ and growth effectiveness, SDZR_A = sustainable development of zakat recipients after zakat, A = after zakat

\subsection{Analysis of the Moderating Effects}

Henseler \& Fassott (2010) suggest that the moderating effects are conjured by variables, whose variation influences the strength or the direction of the relationship between an exogenous and an endogenous variable. The authors further state that, researchers using partial least squares path modelling, need appropriate means to test their models for such moderating effects. In that respect, Akter et al. (2011) explain that, in fact, path modelling offers more precise estimates of moderating effects for the measurement error that attenuates the estimated relationships and improves the validation of theories, referring to Chin, Marcolin, \& Newsted (2003). In a nutshell, PLS path modelling provides robust solutions (including moderating ones) when the objective is prediction in a model that is moderately complex, and the phenomenon is evolving to a newer dimension (Akter et al., 2011). 


\subsubsection{Discriminant Analysis in the Moderation Model}

In the analysis of discriminant validity shown in Table 10, the HTMT criteria fulfil the necessary requirements of the model.

Table 10.

Discriminant Validity (HTMT) (Before and After Zakat)

\begin{tabular}{|c|c|c|c|c|c|}
\hline \multicolumn{3}{|c|}{ Before } & \multicolumn{3}{|c|}{ After } \\
\hline & ICP & SDZR_B & & ICP & SDZR_A \\
\hline ICP & -------- & & ICP & --------- & \\
\hline SDZR_B & $\begin{array}{c}0.443 \\
\mathrm{CI}_{0.90}[0.393 ; 0.504]\end{array}$ & ----------- & SDZR_A & $\begin{array}{c}0.412 \\
\mathrm{CI}_{0.90}[0.344 ; 0.468]\end{array}$ & \\
\hline
\end{tabular}

Note: SDZR_B = sustainable development of zakat recipients before zakat, SDZR_A = sustainable development of zakat recipients after zakat, $\mathrm{ICP}=$ institutional contributory performance

\subsubsection{Path Analysis in the Moderation Model}

In Table 11, the relationship between institutional contributory performance and the sustainable development of zakat recipients is shown, with the path coefficients demonstrating that the decisions are supported (before: ICP $->$ SDZR_B, $\beta=0.284$, $\mathrm{t}=4.545$ and $\mathrm{p}<0.01$ ) and (after: ICP $\rightarrow$ SDZR_A, $\beta=0.383, \mathrm{t}=9.902$ and $\mathrm{p}<0.01$ ).

Table 11.

Path Coefficients Before and After Zakat

\begin{tabular}{lcccccccc}
\hline \multirow{2}{*}{ Hs } & \multirow{2}{*}{ Relationship } & \multirow{2}{*}{ Beta } & \multirow{2}{*}{ SE } & \multirow{2}{*}{ t value } & p value & \multirow{2}{*}{ Decision } & \multicolumn{2}{c}{ CI (BC) } \\
\cline { 3 - 8 } & & \multicolumn{8}{c}{ Before Zakat } & UL \\
\hline H1_B & ICP $>$ SDZR_B & 0.284 & 0.062 & 4.545 & 0.000 & Supported & 0.189 & 0.408 \\
\hline \multicolumn{8}{c}{ After Zakat } \\
\hline H1_A & ICP $>$ SDZR_A & 0.383 & 0.039 & 9.902 & 0.000 & Supported & 0.322 & 0.461 \\
\hline
\end{tabular}

Note: $\mathrm{Hs}=$ hypotheses, $\mathrm{B}=$ before zakat, $\mathrm{A}=$ after zakat, $\mathrm{CI}(\mathrm{BC})=$ confidence interval (bias corrected), $\mathrm{LL}=$ lower limit, $\mathrm{UL}=$ upper limit, SDZR_B = sustainable development of zakat recipients before zakat, ICP= institutional contributory performance

Conversely, when the analysis did the bootstrapping for the moderation effect of 'individual items', like age, gender, marital status, earnings, unfortunately, the results demonstrate that the decision is not supported (tables 13 and 14). Therefore, it becomes truly pertinent for future analysis why 'individually' the four demographic items failed to establish any moderating effect on the model. It is equally important to note that these demographic characteristics are important and were analysed to understand the interaction effects in different studies (Akram et al., 2016; Bierman, 2012; Henrique et al., 2015; Memon et al., 2019). 
Table 12.

Moderation Effect (Before Zakat)

\begin{tabular}{lcccccccc}
\hline \multirow{2}{*}{ Hs } & \multirow{2}{*}{ Relationship } & \multirow{2}{*}{ Beta } & \multirow{2}{*}{ SE } & \multirow{2}{*}{ t-value } & P-Values & \multirow{2}{*}{ Decision } & \multicolumn{2}{c}{ CI (BC) } \\
\cline { 7 - 9 } & & & & & & LL & UL \\
\hline H2.1B & Age*ICP -> SDZR_B & -0.081 & 0.099 & 0.821 & 0.412 & Not supported & -0.143 & 0.240 \\
H2.2B & ER*ICP -> SDZR_B & 0.055 & 0.100 & 0.554 & 0.580 & Not supported & -0.178 & 0.129 \\
H2.3B & MS*ICP -> SDZR_B & 0.095 & 0.111 & 0.855 & 0.392 & Not supported & -0.256 & 0.160 \\
H2.4B & Gen*ICP -> SDZR_B & 0.075 & 0.045 & 1.646 & 0.100 & Not supported & -0.199 & 0.125 \\
\hline
\end{tabular}

Note: $\mathrm{Hs}=$ Hypotheses, $\mathrm{B}=$ before zakat, $\mathrm{CI}(\mathrm{BC})=$ Confidence Interval (Bias Corrected), $\mathrm{LL}=$ Lower Limit, $\mathrm{UL}=$ Upper Limit, Er = earnings, MS = marital status, Gen = gender, SDZR_B = sustainable development of zakat recipients before zakat, ICP= Institutional contributory performance

Table 13.

Moderation Effect (After Zakat)

\begin{tabular}{lcccccccc}
\hline \multirow{2}{*}{ Hs } & \multirow{2}{*}{ Relationship } & \multirow{2}{*}{ Beta } & \multirow{2}{*}{ SE } & \multirow{2}{*}{ t-value } & P-Values & \multirow{2}{*}{ Decision } & \multicolumn{2}{c}{ CI (BC) } \\
\cline { 7 - 9 } & & & & & & LL & UL \\
\hline H2.1A & ICP*Age -> SDZR_A & -0.081 & 0.113 & 0.714 & 0.476 & Not supported & -0.174 & 0.246 \\
H2.2A & ICP*Er -> SDZR_A & 0.094 & 0.061 & 1.548 & 0.122 & Not supported & -0.154 & 0.158 \\
H2.4A & ICP*Gen -> SDZR_A & 0.044 & 0.083 & 0.531 & 0.596 & Not supported & -0.219 & 0.127 \\
H2.3A & ICP*MS -> SDZR_A & 0.050 & 0.110 & 0.452 & 0.651 & Not supported & -0.250 & 0.175 \\
\hline
\end{tabular}

Note: Hs = Hypotheses, A = after zakat, CI (BC) = Confidence Interval (Bias Corrected), LL = Lower Limit, UL = Upper Limit, Er = earnings, MS = marital status, Gen = gender, SDZR_A = sustainable development of zakat recipients after zakat, ICP= Institutional contributory performance

\subsection{Coefficient of Determination $\left(\mathbf{R}^{2}\right)$}

Cheah et al. (2018) state that predictive power can be assessed by means of the coefficient of determination score $\left(\mathrm{R}^{2}\right)$. This is in fact a measure of the model's predictive accuracy (Hair et al., 2014) and can also be regarded as the combined effect of the exogenous variables on the endogenous variables. In the afterzakat scenario (Table 14), the value stands at 0.208, an acceptable level, which demonstrates that the moderation in fact helped to strengthen the $\mathrm{R}^{2}$ in the afterzakat model, although it was weak (0.124) in the before-zakat scenario.

Table 14.

Coefficient of Determination $\left(\mathbf{R}^{2}\right)$ (Before and After Zakat)

\begin{tabular}{lcc}
\hline Exogenous Variable & R Square of SDZR_B & R Square of SDZR_A \\
\hline ICP & 0.124 & 0.208 \\
\hline
\end{tabular}

Note: $\mathrm{ICP}=$ institutional contributory performance, SDZR_B = sustainable development of zakat recipients before zakat, SDZR_A = sustainable development of zakat recipients after zakat

\subsubsection{Effect Size $\left(f^{2}\right)$}

According to Cohen (1988), effect sizes are termed as small (0.02), medium (0.15) or large (0.35). In evaluating the effect size, Chin et al. (2003) posited that the result should not be ignored even if the effect size is small, since a small interaction effect can be meaningful under extreme moderating conditions. After zakat $\left(f^{2} \_\mathrm{A}=\right.$ 0.178 ) the result is incremental (see table 15), which signifies that the moderation model has implications that to reckon with. 
Table 15.

Effect Size ( $\left(^{2}\right)$ (Before and After Zakat)

\begin{tabular}{lcccc}
\hline \multirow{2}{*}{ Exogenous Variable } & \multicolumn{2}{c}{ Before } & \multicolumn{2}{c}{ After } \\
\cline { 2 - 5 } & $\begin{array}{c}\text { Endogenous } \\
\text { Variable }\end{array}$ & $\mathbf{f}^{2}$ Value & $\begin{array}{c}\text { Endogenous } \\
\text { Variable }\end{array}$ & $\mathbf{f}^{2}$ Value \\
\hline ICP & SDZR_B & 0.089 & SDZR_A & 0.178 \\
\hline
\end{tabular}

Note: ICP = institutional contributory performance, SDZR_B = sustainable development of zakat recipients before zakat, SDZR_A = sustainable development of zakat recipients after zakat

\subsubsection{Predictive Relevance $\left(Q^{2}\right)$}

$A Q^{2}$ value higher than zero for a particular endogenous construct indicates the path model's predictive relevance for the particular construct (Hair et al., 2014). In the analyses below (Table 16), it is clear that the $\mathrm{Q}^{2}$ values in both the before and after models are above zero $\left(\mathrm{Q}^{2}{ }_{-} \mathrm{B}=0.040 ; \mathrm{Q}^{2}{ }_{-} \mathrm{A}=0.074\right)$, and that $\mathrm{Q}^{2}$ is incremental in the after-zakat scenario, signifying that the path model has predictive relevance, along with the understanding that zakat assistance do play an impact, and hence the model is indeed acceptable.

Table 16

Predictive Relevance $\left(Q^{2}\right)$ (Before and After Zakat)

\begin{tabular}{lcc}
\hline Exogenous Variable & Q Square of SDZR_B & Q Square of SDZR_A \\
\hline ICP & 0.040 & 0.074 \\
\hline
\end{tabular}

Note: ICP= institutional contributory performance, SDZR_B = sustainable development of zakat recipients before zakat, SDZR_A = sustainable development of zakat recipients after zakat

\subsection{Understanding the Level of Sustainable Development of Zakat Recipients (SDZR) Before and After Zakat in Relation to Institutional Contributory Performance (ICP)}

To comprehend the level of SDZR before and after zakat, it is necessary to understand how the ICP affects the SDZR. In Table 11, it can be seen that the $\beta$ (ICP to SDZR_B) is 0.284 before zakat, whereas after zakat (ICP to SDZR_A) it rises to 0.383 , which proves that the overall sustainability has become better off in after zakat. In theory, if the $t$ values are significant, and the $\beta$ s are positive, this explains that for every unit increase in the predictor variable, the outcome variable will increase by the $\beta$ value. In the after-zakat scenario, the results are more assuring, signifying that the outcome variable demonstrates an enhanced causal relationship. Moreover, the $\mathrm{R}^{2}, f^{2}, \mathrm{Q}^{2}$ (Tables 14, 15, and 16) and the CR (Table 17) all improved in the after-zakat-scenario, may equally suggest that the model has an implication in explaining sustainability, and the results further suggest that zakat assistance has an impact, and additionally, the moderation analysis signifies that the study as a whole contributes immensely to knowledge. 
Table 17.

Composite Reliability (Before and After Zakat) *

\begin{tabular}{lcc}
\hline & Before & After \\
\hline Economic Factor & 0.87 & 0.904 \\
Social Factor & 0.875 & 0.949 \\
Environmental Factor & 0.923 & 0.928 \\
Islamic Self-Actualisation & 0.936 & 0.94 \\
\hline
\end{tabular}

*Summarised from Tables 4 and 5.

\subsection{Discussion of the Findings}

From the demographic analysis, the questions that can be raised, whether the empowerment regime is effective enough and truly performing, secondly, is the skills development given true emphasis or the required level of priority, thirdly, because the door to seek for easy-zakat or other help is open, is that unnecessarily making these zakat seekers complacent and forcing them not looking for other adequate means of work to sustain otherwise, requires a thorough scrutiny by the researchers in the future.

\subsubsection{Determinant Findings}

After examining the impact of ICP on the SDZR in the context of KSM, the overall findings are impressive. Hypotheses H1_B and H1_A related to ICP on the SDZR are supported in both the before-zakat and after-zakat scenarios. The results signify that the models are acceptable and the underlying stakeholder theory fits well with the model.

Although the hypotheses concerning customer effectiveness and financial effectiveness are positive in the after-zakat scenario (Table 9), BSC theory (and in retrospect stakeholder theory) demands that the emphasis should be on achieving all the targets, i.e., all the perspectives such as financial, internal, customer, learning and growth, and that all are rightly directed towards effectiveness.

The research then tried to identify whether the demographic characteristics, such as age, earnings, marital status or gender, had any moderating effect. On a positive note, the $\mathrm{R}^{2}, f^{2}$ and the $\mathrm{Q}^{2}$ are all significant and clearly progressive in the after-zakat scenario. This implies what Chin et al. (2003, p. 211) argue, that a small effect size may not in essence mean that the underlying moderating effect is insignificant, rather "a small interaction effect can be meaningful under extreme moderating conditions, if the resulting beta changes are meaningful, then it is important to take these conditions into account" is true. Essentially, after moderation, the pre- and post-zakat $\beta$ s are significant and improving ( $\beta \_B$ $=0.284$ before zakat and $\beta \_A=0.383$ after zakat). This rather exemplifies that the moderation model as a whole has a significant impact and importance, even though individual item assessment may fail to show any positive results.

And lastly, the $\beta$ value is 0.284 in before-zakat and whereas, in the afterzakat, it is raised to 0.383 , which otherwise proves that the overall sustainability has become better-off in after-zakat-scenario. And in the after-zakat, the results are more assertive $(0.383>0.284)$, signifying that in the after-zakat-scenario, the 
outcome variable is demonstrating an enhanced causal relationship, due to better $\beta$ value in after-zakat. Furthermore, these results (in before and after zakat) equally signify that the sustainability is linked to ICP to a notable extent. Therefore, it can be stated that (i) ICP has a positive impact on SDZR, (ii) ICP can considerably improve SDZR, and (iii) the demographic characteristics as a whole can strengthen the relationship between ICP and SDZR.

\section{CONCLUSION AND RECOMMENDATIONS}

\subsection{Conclusion}

The study attempted to contribute immensely by asking, addressing, assessing, analysing, and subsequently recommending the main issues that relates to zakat's bottlenecks, such as, SDZR, ICP, demographic implications, reasons of customer's unhappiness, issues with fund utilisation and $S Q$, the overall perception from the stakeholders in regard to ZI, feedback mechanism, processes and appreciation, issues regarding care, need, expectations, approachability, priorities, institutional efficiency and effectiveness, distributive wisdom and innovativeness, training, guidelines, and ways to augment recipients' income to empower them and make them truly self-sufficient.

By asking these above questions from asnaf, the study attempted to grasp the essence of issues at the core. The recipients were also asked, in particular in regard to basic need fulfilment, ability to generate income, levels of savings, their entrepreneurial aptitude, their social standing, their accessibility to clean water and decent living, adaptation to calamities, and their religious and faith abilities after receiving the zakat assistance. In addition, the study attempted to understand their level of health and how they are coping in maintenance of their property, their intellectual upbringing and also their children's welfare.

Though institutional issues such as financial effectiveness, customer satisfaction, SQ, internal effectiveness, and learning and growth measures are raised and recommended in different zakat topics and literature, similarly the sustainability issues and the importance of demographic characteristics, but, understanding their 'interconnectedness' and studying in entirety, is the real contribution of this study. Furthermore, institutional factors impact on ISA beyond traditional sustainability paradigm, as well as seeing the total impact on asnaf's sustainability, is a significant contribution to the body of knowledge. And the model is in better shape after the moderation-analysis.

Therefore, this research in particular can provide a clear direction in regard to understanding the importance of bettering the zakat's overall system, effectivising the knowledge area with operational technology transfer to the ground, and in fact, to make the asking ones become truly self-reliant and empowered, as that will inevitably help them to fulfil basic needs with ease and comfort, and also to cope adverse calamities. These augmentations will undoubtedly lead them to financial independence. The above-mentioned developments will sooner or later help the recipients to have better faith activities in their spare time, improve their social status, and that will effortlessly deliberate more on healthy living and earning, and their children will have better upbringing in a far conducive environment. 


\subsection{Recommendations}

The findings provide impactful outcomes on practical decisions through constructive recommendations, in regard to improving the zakat sector. The study also delivers a theoretical contribution and similarly enhances the managerial vision and focus, to look for a hands-on solution to asnaf issues, which is equally noteworthy. The ZA need to look into the dynamic aspects of total sustainability keeping in view the contributory performative aspects of zakat management to ensure long-term viable-empowerment of the asnaf who are gaining knowledge and skills slowly but steadily, and can be out-of-the-asking-box with added support, and making them self-reliant in the shortest time frame. The ZI need to understand that the effective fund utilisation requires right measures at the very right-hour. With very meagre assistance, financial or otherwise, it's hard to expect one to be out from an asking basket in the near future. Therefore, a suitable, long term sustainable, viable and above all durable mechanism is required to lift the asnaf from this asking-basket-syndrome. Only adequate skills development, with ensuring decent lifestyle, which can make a zakat seeker think far-and-wide, and can have a vision to perform in life.

\section{REFERENCES}

Abdelmawla, M. A. (2014). The impacts of zakat and knowledge on poverty alleviation in sudan: An empirical investigation (1990-2009). Journal of Economic Cooperation $\mathcal{E}$ Development, 35(4), 61-84.

Abioye, M. M. O., Mohamad, M. H. S., \& Adnan, M. A. (2011). Antecedents of zakat payers' trust: The case of Nigeria. International Journal of Economics, Management and Accounting, 19(3), 133-163.

Abioye, M. M. O., Mohamad, M. H. S., \& Adnan, M. A. (2013). Antecedents of zakat payers' trust in an emerging zakat sector: an exploratory study. Journal of Islamic Accounting and Business Research, 4(1), 4-25.

Abubakar, Y. S. (2016). Corporate social responsibility of Islamic financial institutions: A look from the Maqasid Al-Shariah (purpose of Shariah) approach. Business and Economics Journal, 7(4), 1-4.

Adnan, N. S., Kamaluddi, A., \& Kasim, N. (2013). Intellectual capital in religious organisations: Malaysian zakat institutions perspective. Middle East Journal of Scientific Research, 16(3), 368-377.

Ahmadi, M. (2016). Sustainable Development-Islamic Perspectives. 1st International Conference on Rethinking the Sustainable Development ( $1^{\text {st }}$-ICORESD), Tabriz, Iran Earth Charter.

Ahmed, B. O., Johari, F., \& Abdul Wahab, K. (2017). Identifying the poor and the needy among the beneficiaries of zakat: Need for a zakat-based poverty threshold in Nigeria. International Journal of Social Economics, 44(4), 446-458.

Akram, U., Hui, P., Khan, M. K., Hashim, M., \& Rasheed, S. (2016). Impact of store atmosphere on impulse buying behaviour: Moderating effect of demographic variables. International Journal of $u$-and e-Service, Science and Technology, 9(7), 43-60.

Akter, S., D'Ambra, J. \& Ray, P. (2011). An evaluation of PLS based complex models: the roles of power analysis, predictive relevance and GoF index. 
Proceedings of the 17th Americas Conference on Information Systems (AMCIS2011) (pp. 1-7). Detroit, USA: Association for Information Systems.

Alam, M.M., Wahab, N.A., Haq, M.A.A. \& Ahmad, S.A. (2021). Sustainable development status of zakat recipients: Empirical investigation based on Malaysia's Kedah State. Journal for Global Business Advancement, 14(4), forthcoming.

Alarcón, D., Sánchez, J. A., \& De Olavide, U. (2015, October). Assessing convergent and discriminant validity in the ADHD-R IV rating scale: User-written commands for Average Variance Extracted (AVE), Composite Reliability (CR), and Heterotrait-Monotrait ratio of correlations (HTMT). In Spanish STATA Meeting (pp. 1-39).

Ali, M., Fahme, A., Noor, M., Aziz, A., Ridhwan, M., Ibrahim, M. F., \& Johari, F. (2013). Impact of zakat distribution on poor and needy recipients: An analysis in Kelantan, Malaysia. Australian Journal of Basic E Applied Sciences, 7(13), 177182.

Al-Mubarak, T. (2016). The Maqasid of zakah and awqaf and their roles in inclusive finance. Islam and Civilisational Renewal Journal, 7(2), 1-14.

Anis, F. M., \& Kassim, S. H. (2016). Effectiveness of zakat-based programs on poverty alleviation and economic empowerment of poor women: A case study of Bangladesh. Journal of Islamic Monetary Economics and Finance, 1(2), 229-258.

Aris, N. A., Rahman, S. A., Othman, R., \& Chik, W. M. Y. W. (2017). The Maqasidbased Sustainability Index for Cooperatives. In Symposium on Innovation and Creativity (iMIT-SIC) (Vol. 1, pp. 1-4).

Ariyani, N. (2016). Zakat as a sustainable and effective strategy for poverty alleviation: From the perspective of a multi-dimensional analysis. International Journal of Zakat, 1(1), 88-106.

Asri, M. A. B. M. (2011). Keberkesanan pengagihan zakat terhadap asnaf: Kajian kumpulan usahawan asnaf zakat negeri Pulau Pinang [The effectiveness of the zakat distribution to asnaf: A study of the Penang state zakat asnaf Entrepreneurs Group]. Malaysia: Universiti Utara Malaysia, Master's thesis.

Avkiran, N. K. (2018). Rise of the partial least squares structural equation modeling: An application in banking. In Partial Least Squares Structural Equation Modeling (pp. 1-29). Switzerland: Springer, Cham.

Bakar, N. B. A., \& Rashid, H. M. A. (2010). Motivations of paying zakat on income: Evidence from Malaysia. International Journal of Economics and Finance, 2(3), 7684.

Bieker, T. (2003). Sustainability Management with the Balanced Scorecard. In proceedings of 5th International Summer Academy on Technology Studies, Karner, S., Oehme, I. and Seebacher, U. (eds.). Corporate Sustainability, Deutschlandsberg, Austria, 13-19 July 2003, 17-34.

Bierman, A. (2012). Functional limitations and psychological distress: Marital status as moderator. Society and Mental Health, 2(1), 35-52.

Bougie, R., \& Sekaran, U. (2016). Research methods for business: A skill building approach. River Street Hoboken, USA: John Wiley \& Sons.

Buckmaster, N. (1999). Associations between outcome measurement, accountability and learning for non-profit organisations. International Journal of Public Sector Management, 12(2), 186-197. 
Cheah, J. H., Memon, M. A., Chuah, F., Ting, H., \& Ramayah, T. (2018). Assessing reflective models in marketing research: A comparison between PLS and PLSc estimates. International Journal of Business and Society, 19(1), 139-160.

Chin, W. W., Marcolin, B. L., \& Newsted, P. R. (2003). A partial least squares latent variable modelling approach for measuring interaction effects: Results from a monte carlo simulation study and an electronic-mail emotion/adoption study. Information systems research, 14(2), 189-217.

Chuah, S. H. W., Rauschnabel, P. A., Marimuthu, M., Thurasamy, R., \& Nguyen, B. (2017). Why do satisfied customers defect? a closer look at the simultaneous effects of switching barriers and inducements on customer loyalty. Journal of Service Theory and Practice, 27(3), 616-641.

Cohen, J. (1988). Statistical power analysis for the behavioral sciences ( $2^{\text {nd }}$ edition). New Jersey, USA: Routledge.

Dusuki, A. W., \& Bouheraoua, S. (2011). The framework of maqasid al-shari'ah and its implication for Islamic finance. Islam and Civilisational Renewal Journal, 2(2), 316 .

Hair, J. F., Sarstedt, M., Pieper, T. M., \& Ringle, C. M. (2012). The use of partial least squares structural equation modelling in strategic management research: A review of past practices and recommendations for future applications. Long Range Planning, 45(5-6), 320-340.

Hair, J. F., Ringle, C. M., \& Sarstedt, M. (2013). Partial least squares structural equation modelling: Rigorous applications, better results and higher acceptance. Long Range Planning, 46(1-2), 1-12.

Hair Jr, J. F., Sarstedt, M., Hopkins, L., \& Kuppelwieser, V. G. (2014). Partial least squares structural equation modeling (PLS-SEM): An emerging tool in business research. European Business Review, 26(2), 106-121.

Halim, H. A., Said, J., \& Yusuf, S. N. S. (2012). Individual characteristics of the successful asnaf entrepreneurs: Opportunities and solutions for zakat organization in Malaysia. International Business and Management, 4(2), 41-49.

Halimatusa'diyah, I. (2015). Zakat and social protection: The relationship between socio-religious CSOs and the government in Indonesia. Journal of Civil Society, 11(1), 79-99.

Haq, A., Ashraf, M., \& Abd Wahab, N. (2017). Effective zakat distribution: Highlighting few issues and gaps in Kedah, Malaysia. Al-Iqtishad: Journal of Islamic Economics, 9(2), 259-288.

Hasan, Z. (2006). Sustainable development from an Islamic perspective: Meaning, implications, and policy concerns. Journal of King Abdulaziz University: Islamic Economics, 19(1), 3-18.

Hashem, E. A., \& El-sha'er, S. (2015). Can zakat help to enhance financial inclusion? case study Egypt. International Journal of Education and Research, 3(3), 413-432.

Hassan, N. M. N. (1987). Zakat in Malaysia: Present and future status. IIUM Journal of Economics and Management, 1(1), 47-75.

Henrique, J. L., \& De Matos, C. A. (2015). The influence of personal values and demographic variables on customer loyalty in the banking industry. International Journal of Bank Marketing, 33(4), 571-587.

Henseler, J., \& Fassott, G. (2010). Testing moderating effects in PLS path models: An illustration of available procedures. In Handbook of Partial Least Squares (pp. 713-735). Berlin: Springer. 
Homburg, C., \& Giering, A. (2001). Personal characteristics as moderators of the relationship between customer satisfaction and loyalty-An empirical analysis. Psychology \& Marketing, 18(1), 43-66.

Hubbard, G. (2009). Measuring organizational performance: Beyond the triple bottom line. Business Strategy and The Environment, 18(3), 177-191.

Ibrahim, P., \& Ghazali, R. (2014). Zakah as an Islamic micro-financing mechanism to productive zakah recipients. Asian Economic and Financial Review, 4(1), 117125.

Ibrahim, S. M. (2015). The role of zakat in establishing social welfare and economic sustainability. International Journal of Management and Commerce Innovations, 3(1), 437-441.

Kamali, M. H. (2011). Maqasid al-shari'ah and ijtihad as instruments of civilisational renewal: A methodological perspective. Islam and Civilisational Renewal, 2(2), 245-271.

Kamaruddin, R., \& Samsudin, S. (2014). The sustainable livelihoods index: A tool to assess the ability and preparedness of the rural poor in receiving entrepreneurial project. Journal of Social Economic Research, 1(6), 108-117.

Kaplan, R. S., and Norton, D. P. (1992). The balanced scorecard: Measures that drive performance. Harvard Business Review, January-February (1992), 71-79.

Kaplan, R. S. (2001). Strategic performance measurement and management in nonprofit organizations. Nonprofit management and Leadership, 11(3), 353-370.

Kaplan, R. S. (2009). Conceptual foundations of the balanced scorecard. Handbooks of Management Accounting Research, 3, pp. 1253-1269.

Khalili, N. R. (2011). Business Case for Sustainability. In Practical Sustainability (pp. 79-99). New York: Palgrave Macmillan.

Kothari, C.R. (2009). Research methodology methods and techniques, 2 nd Revised Edition. Ansari Road, Daryaganj, New Delhi: New Age International Publishers.

Koufteros, X. A. (1999). Testing a model of pull production: A paradigm for manufacturing research using structural equation modelling. Journal of Operations Management, 17(4), 467-488.

MacKrell, D., Houghton, L., \& Campbell, J. (2011). Just not-for-profit: Supporting sustainability with business intelligence in the not-for-profit sector. MCIS 2011 Proceedings. Paper 52.

Mahamod, L. H. (2011). Alleviation of rural poverty in Malaysia: the role of Zakat, a case study. Scotland: University of Edinburgh. PhD dissertation.

Memon, M. A., Cheah, J. H., Ramayah, T., Ting, H., Chuah, F., \& Cham, T. H. (2019). Moderation analysis: Issues and guidelines. Journal of Applied Structural Equation Modeling, 3(1), 1-11.

Mohammad, M. T. S. H. (2015). Theoretical and trustees' perspectives on the establishment of an Islamic social (Waqf) bank. Humanomics, 31(1), 37-73.

Mohsin, M. I. A., \& Ismail, M. (2013). Potential of zakat in eliminating riba and eradicating poverty in Muslim countries. EJBM-Special Issue: Islamic Management and Business, 5(11), 40-63.

Muda, M., Marzuki, A., \& Shaharuddin, A. (2009). Factors influencing individual participation in zakat contribution: Exploratory investigation. Paper submitted for presentation at the Seminar for Islamic Banking and Finance 2006 (iBAF2006), 29 - 30 August 2006, Kuala Lumpur (Faculty of Economics and Muamalat, KUIM, Nilai NS). 
Muhammad, S. A., \& Saad, R. A. J. (2016). Moderating Effect of Attitude toward Zakat Payment on the Relationship between Moral Reasoning and Intention to Pay Zakat. Procedia-Social and Behavioral Sciences, 219, 520-527.

Neely, A. D., Adams, C., \& Kennerley, M. (2002). The performance prism: The scorecard for measuring and managing business success. London: Financial Times/ Prentice Hall.

Noordin, N. H., Haron, S. N., \& Kassim, S. (2017). Developing a comprehensive performance measurement system for waqf institutions. International Journal of Social Economics, 44(7), 921-936.

Nurzaman, M. S. (2011). Zakat and human development: An empirical analysis on poverty alleviation in Jakarta, Indonesia. 8th International Conference on Islamic Economics and Finance (19-21 December, 2011), Doha, Qatar 1-26.

Parihar, P., Dawra, J., \& Sahay, V. (2019). The role of customer engagement in the involvement-loyalty link. Marketing Intelligence E Planning, 37(1), 66-79.

Petrini, M., \& Pozzebon, M. (2009). Managing sustainability with the support of business intelligence: Integrating socio-environmental indicators and organisational context. The Journal of Strategic Information Systems, 18(4), 178191.

Ponterotto, J. G., \& Ruckdeschel, D. E. (2007). An overview of coefficient alpha and a reliability matrix for estimating adequacy of internal consistency coefficients with psychological research measures. Perceptual and Motor Skills, 105(3), 9971014.

Prahalad, C. K., \& Hamel, G. (1994). Strategy as a field of study: Why search for a new paradigm? Strategic Management Journal, 15(S2), 5-16.

Price, C. E. (2011). Women and the environment: Mediating and moderating effects of gender and demographic characteristics of environmental concern. Knoxville, United States: University of Tennessee. PhD Thesis.

Rudito, P. (2010). An Investigation into The Role of Moderating Variables on Mobile Broadband Technology Acceptance in Indonesia. Melbourne: RMIT University. PhD thesis.

Saad, R. A. J., Wahab, M. S. A., \& Samsudin, M. A. M. (2016). Factors influencing business zakah compliance behavior among Moslem businessmen in malaysia: A research model. Procedia-Social and Behavioral Sciences, 219, 654-659.

Said, J., Halim, H. A., Yusuf, S. N. S., \& Smith, M. (2014). A comparative study of successful male and female entrepreneurs: The case of the Selangor zakat board (SZB). International Review of Social Sciences and Humanities, 7(1), 125-135.

Said, J., Yusuf, S. N. S. (2011). Poverty alleviation projects of zakat distribution: The role of organizational learning in ensuring project success. $8^{\text {th }}$ International Conference on Islamic Economics and Finance (19-21 December, 2011), Doha, Qatar.

Sarea, A. (2012). Zakat as a benchmark to evaluate economic growth: An alternative approach. International Journal of Business and Social Science, 3(18), 242-245.

Sarkawi, A. A., Abdullah, A., Dali, N. M., \& Salim, N. A. (2015a). Integrating sustainability indicators in Malaysia with maqasid al shariah (the objective of Islamic law), Proceedings of ADVED15 International Conference on Advances in Education and Social Sciences (12-14 October 2015), Istanbul, Turkey, pp 395-406. 
Sarkawi, A. A., Abdullah, A., Kamaruddin, Z., Salim, N. A., \& Dali, N. M. (2015b). A survey on the understanding of maqasid al-shari'ah among local authorities in Malaysia in the pursuit of urban sustainability, Researchgate.net, 1-16.

Saunders, M., Lewis, P., \& Thornhill, A. (2007). Research methods for business students, $4^{\text {th }}$ Edition. Edinburgh Gate, Harlow: Financial Times Prentice Hall.

Sekaran, U. (2003). Research methods for business-A skill building approach, $4^{\text {th }}$ Edition. New York: John Wiley and Sons Inc.

Senadjki, A., \& Sulaiman, J. (2015). An empirical study on the influence of Islamic values in poverty alleviation. Journal of Islamic Accounting and Business Research, 6(2), 222-243.

Steurer, R., Langer, M. E., Konrad, A., \& Martinuzzi, A. (2005). Corporations, stakeholders and sustainable development I: A theoretical exploration of business-society relations. Journal of Business Ethics, 61(3), 263-281.

Strange, T. \& Bayley, A. (2008). OECD insights sustainable development linking economy, society, environment: Linking economy, society, environment. Paris: OECD Publishing.

Taha, R., Ali, N. N. M., Embong, M. R., \& Nor, M. N. M. (2014). Developing a multidimensional performance of zakat collection system in East Coast Region. Procedia-Social and Behavioral Sciences, 164, 84-90.

Tajuddin, T. S. B., Aman, Z. B., \& Ismail, S. B. (2014). Management accounting practices in non-profit religious organisation: a case study in Lembaga Zakat Selangor (LZS). E-proceedings of the Conference on Management and Muamalah (CoMM 2014), 26-27 May 2014 Synergizing Knowledge on Management and Muamalah (E-ISBN: 978-983-3048-92-2), 309-320.

The Holy Qur'an, www.quran.com and Holy Hadith from sources.

Waddock, S. A., \& Graves, S. B. (1997). The corporate social performance-financial performance link. Strategic Management Journal, 18(4), 303-319.

Wahab, N. A. \& Abdul-Rahman, A. R. (2011). A Framework to analyse the efficiency \& governance of zakat institutions. Journal of Islamic Accounting and Business Research, 2(1), $43-62$.

Wahab, N. A., Zainol, Z., Bakar, M. A., Ibrahim, A. Z., \& Minhaj, N. (2016). Developing service quality index for zakat institutions. International Journal of Economics and Financial Issues, 6(7S), 249-258.

Wahab, N. Abd., Zainol, Z., \& Abu Bakar, M. (2017). Towards developing service quality index for zakat institutions. Journal of Islamic Accounting and Business Research, 8(3), 326-333.

Wahid, H., \& Kader, R. A. (2010). Localization of Malaysian zakat distribution: Perceptions of amil and zakat recipients. $7^{\text {th }}$ International Conference - The Tawhidi Epistemology: Zakat and Waqf Economy, Bangi 2010, 461-483.

Wahid, H., Kader, R. A., \& Ahmad, S. (2011). Localization of zakat distribution and the role of Mosque: perceptions of amil and zakat recipients in Malaysia. In International Zakat Forum 2011 (pp. 1-25), https://scholar.google.com/ citations?view_op=view_citation \&hl=en\&user=Sp-mv0IAAAAJ\&alert_ preview_top_rm=2\&citation_for_view=Sp-mv0IAAAAJ:YsMSGLbcyi4C.

Wardiwiyono, S. (2013). Towards sustainable success through corporate social responsibility disclosure: An Islamic approach. International Journal of Green Economics, 7(1), 86-101. 
Zainal, H., Bakar, A. A., \& Saad, R. A. J. (2016). Reputation, satisfaction of zakat distribution, and service quality as determinant of stakeholder trust in zakat institutions. International Journal of Economics and Financial Issues, 6(S7), 72-76.

Zulkifli, M. F. B., Taha, R. B., \& Embong, M. R. B. (2014). Establish a balance scorecard approach to enhance zakat distribution system in East Coast Region. MIICEMA 2014, 391-405. 
This page is intentionally left blank 